Portland State University

PDXScholar

3-1-2019

\title{
Transfer-Printed Gastroliths: Fowl-Ingested Artifacts and Identity at Fort Vancouver's Village
}

\author{
Emily C. Taber \\ Applied Archaeological Research, Inc. \\ Douglas C. Wilson \\ Portland State University, doug@pdx.edu \\ Robert Cromwell \\ Fort Vancouver National Historic Site \\ Katie A. Wynia \\ Portland State University, kwynia@pdx.edu \\ Alice Knowles
}

Follow this and additional works at: https://pdxscholar.library.pdx.edu/anth_fac

Part of the Anthropology Commons

Let us know how access to this document benefits you.

\section{Citation Details}

Published as: Taber, E. C., Wilson, D. C., Cromwell, R., Wynia, K. A., \& Knowles, A. (2019). Transfer-Printed Gastroliths: Fowl-Ingested Artifacts and Identity at Fort Vancouver's Village. Historical Archaeology, 53(1), 86-102.

This Post-Print is brought to you for free and open access. It has been accepted for inclusion in Anthropology Faculty Publications and Presentations by an authorized administrator of PDXScholar. Please contact us if we can make this document more accessible: pdxscholar@pdx.edu. 
[Cover Page]

Emily C. Taber

Applied Archaeological Research, Inc., 4001 NE Halsey St., Ste 3, Portland, OR 97232

Work: (503) 281-9451; Home: (303)524-2147; email emily@aar-crm.com

Douglas C. Wilson

US National Park Service and Anthropology Department, Portland State University, P.O.

Box 751, Portland OR 97201

Work: (360) 921-5241; Home: (360) 693-0781; email doug_wilson@ nps.gov

Robert Cromwell

Fort Vancouver National Historic Site, 1501 E. Evergreen Blvd., Vancouver, WA, 98661

Work: (360) 816-6253; Home: (360) 931-3265; email: bob_cromwell@ nps.gov

Katie A. Wynia

Fort Vancouver National Historic Site, 1501 E. Evergreen Blvd., Vancouver, WA, 98661

Work: 360 816-6250; Home: (651) 792-6040; email: katie_wynia@ partner.nps.gov

Alice Knowles

Address N/A; correspondence sent c/o Emily C. Taber, address above

Work: N/A Home: (240)357-8384; email: knowles.aliceo@ gmail.com 
[Author Names; Title; Abstract]

Emily C. Taber

Douglas C. Wilson

Robert Cromwell

Katie A. Wynia

Alice Knowles

Transfer-Printed Gastroliths: Fowl-ingested Artifacts and Identity at Fort Vancouver's Village

\begin{abstract}
Transfer-printed ceramics and other objects ingested by fowl provide unique data on the household production associated with a fur trade center in the Pacific Northwest. Gastroliths are an indicator of the use of avifauna at archaeological sites, specifically of the order Galliformes. The presence of ceramic and glass gastroliths at house sites within Fort Vancouver's Village provide evidence for the keeping and consumption of domestic fowl including chickens and turkeys. The presence and concentration of these artifacts, combined with documentary and other evidence, provides clues on household economies in a culturally diverse colonial setting. While ethnic backgrounds of the Villagers included Native Hawai'ian, American Indians, French Canadians, English, and Americans, archaeological and archival evidence points to shared practices emerging within the Fort Vancouver Village.
\end{abstract}

KEY WORDS: gastrolith - avifauna - identity - fort - foodways - household economy 
Introduction

Ceramic and glass artifacts from recent excavations at the Hudson's Bay Company (HBC) Village at Fort Vancouver National Historic Site provide evidence for food consumption in the pluralistic colonial community. These assemblages include 67 gastroliths of ceramic and glass, indicating the production and consumption of domesticated fowl that is otherwise unrepresented in the faunal assemblage. Gastroliths are small, hard objects ingested by fowl to aid digestion, and are typically stone, but can be other materials, including ceramics and glass. Research into the use and consumption of animals at fur trade sites has furthered our understanding of food choice and identity, leading to compelling questions about how colonial communities navigated these issues (e.g., Lightfoot et al. 1998; Hamilton 2000; Vibert 2010; Butler and Martin 2013). Nassaney ( 2015:85-90) argues that fur trade researchers benefit from such studies, because food choices were of major importance within the cultural narrative that defined both identity and the changing sense of belonging in fur-trade discourse. Within Fort Vancouver's Village, the presence and distribution of gastroliths provides a means of understanding a shared practice of domesticated fowl consumption between ethnically diverse households.

Nassaney's (2015:33, this volume) idea of 'belonging' is explored more in the concept of 'glocalization.' Glocalization is the mechanism whereby a global product is considered from both global and local perspectives, specifically to adapt products to local consumers' needs. Frontier traders and consumers transformed fur trade items manufactured from far-away places to function within local markets. When framed through glocalization, the presence of domesticated animals such as fowl doesn't necessarily mean greater Europeanization, but rather a translation of available European foodways into variable frontier ethnicities, while also 
maintaining individual meaning at the local level. Wilson et al. (2017) explored a similar narrative of fur-trade era European and American artifacts in a Chinookan setting in the Middle Village site at the mouth of the Columbia River.

Archaeological discourse on frontier subsistence patterns has emphasized the varying dietary roles of domesticated and wild animal species in fur trade communities, resistance to the adoption of domesticated animals by some Native American groups after European contact (e.g., Pavao-Zuckerman 2007; Deagan 2008; Nassaney 2015), and the expression of cultural identity through both traditional and emerging foodways (Janowitz 1993; Cheek 1998; Voss 2005). Fernandez-Armest (2002:131-162) suggests that foodways are one of the last elements of cultural identity to be altered by sustained cross-cultural contact. In Fort Vancouver's Village, the fusion of local pre-existing social relations and the new, partly ethnic-based, class structures laid out by mercantile capitalists undoubtedly impacted foodways. Evidence of the shared consumption of domesticated avifauna within the Village is an example of frontier glocalization, provides evidence for multiethnic social interactions, and suggests one manner of navigating personal identity in the frontier narrative. Fort Vancouver's central and intermediary role in understanding the historical trajectories of American Indian, Native Hawaiian, and fur trade/settler groups accentuates the significance of this kind of research. It is relevant to modernday groups dispersed by colonial forces long ago. This article augments research on identity and social relations explored through practice theory and related concepts (Bourdieu 1977; Giddens 1984; Ortner 2006) which have led to useful explorations of material culture in colonial settings at Fort Vancouver and elsewhere in the western United States (e.g., Lightfoot et al. 1998; Voss 2005; Tveskov 2007; Mullaley 2011; Wynia 2013; Simmons 2014; Horton 2014). 


\section{Fort Vancouver's Kanaka Village}

Between 1825 and 1860, Fort Vancouver was the headquarters and primary supply depot for the HBC fur trading operations in the Pacific Northwest. The site of Fort Vancouver is situated in Vancouver, Washington, just across the Columbia River from Portland, Oregon (Figure 1). Fort Vancouver's operations by British capitalists were primarily mercantile, seeking to exploit the area's resources through fur trapping, agriculture, and manufacturing (Erigero 1992) for the profit of the Company's shareholders. Although not governmental or militaristic, Fort Vancouver was central to the British mercantilist colonization of the west (Hussey 1957a; Lightfoot 2006; Wilson and Langford 2011). Cromwell (2006: 57) states: “the Company's capitalist goals, and unofficial representation of the English crown make it clear that they were, for better or for worse, the harbingers of European colonial forces and ideals." Fort Vancouver later served as the initial terminus for the great American westward migration on the Oregon Trail and became the first permanent U.S. Army post in the Pacific Northwest. The HBC and the U.S. Army shared the space until 1860, when the HBC moved its operations to Victoria, British Columbia, and the U.S. Army gained control of the entire site(Hussey 1957a; Wilson and Langford 2011; Wilson 2014).

The reported ethnic diversity of employees and their families was high during the HBC period of operations (1823-1860). The elite managers and Catholic missionaries reported that the fur-trade inhabitants of Fort Vancouver included Canadians and French Canadians, English, Metís, Scots, Native Hawai'ians, Africans, and individuals from over 30 Native American Indian groups including people of Cree, Chinook, Iroquois, and Klickitat ancestry (Kardas 1971; Warner and Munnick 1972; Thomas and Hibbs 1984; Wilson 2014). Over the period of 1824 to 1843, church and employee records suggest that the Native Hawai'ian portion of the population 
was between 12 and 43\%, and American Indian men (including Iroquois) composed between 6 and $15 \%$ of the Village inhabitants (Kardas 1971:169). American Indian women comprised about $23 \%$ of the population, with children totaling about 28\% (Kardas 1971:213). While employees of the gentlemen class (primarily of Scottish ancestry, who wielded the Company's authority) lived within the stockade, most other employees and their families lived in houses to the west of the stockade.

This residential area outside the fort stockade was referred to as the Village, or "Kanaka Village" in the 1850s for the many Native Hawai'ian Islander residents (Kardas 1971; Mullaley 2011; Wilson 2014). A field and orchard physically separated the Village from the fort, about $230 \mathrm{~m}(755 \mathrm{ft}$.$) to the west. Laborers were responsible for constructing their own lodging,$ resulting in a hodgepodge of housing styles. These included "American cottage fashion," "Canadian style," and "edged slabs" (from the Company sawmill), in addition to camp-style accommodations used by HBC voyageurs who often lived in open spaces in the Village when at the Fort (Mullaley 2011:11-15). At its zenith, the Village was estimated to house approximately ten people within each dwelling (both families and bachelors although there was no defined bachelor or family housing spaces), which with camps associated with the return of the annual overwintering trapping groups or fur "brigades," suggest a maximum of 1000 residents, including employees (voyageurs and laborers) and their families. Uncertainty in the population is reflected in the reported number of houses, which varies depending on which visitor account is consulted (see Hussey [1957a:218-220]), ranging from 30 (Townsend 1839) to 60 (Alvord 1867). The HBC kept no exact record of houses, though they retained ownership and at least superficial control of all structures on-site until their 1860 departure (Mullaley 2011). 
HBC laborers and Village inhabitants negotiated identity in a colonial setting where the class structure was partially defined by ethnic affiliation as perceived by the company managers (Mullaley 2011). The Company hierarchy was based on an employee's occupation (Ross 1976a:7), and this had some relation to an employee's ethnic background based upon the hiring practices of the HBC. The HBC recruited different nationalities for their characteristics and skills, real or imagined. For example, Hawaiians were valued for their small boat skills (Rogers 1993:40), but the HBC also saw them as cheap labor, suited for "common drudgery" (Roulstone 1975:34; Burley 1997:95). This system created a general sense of an ethnic hierarchy for the Company with Europeans at the top, then French-Canadians, Hawaiians, and finally Native Americans at the bottom (Roulstone 1975:37; Cromwell 2006: 85).

The multi-scalar implementation of ethnicity-as-class is exemplified by George Simpson's 1824 discussion of the Hawaiians as employees of the HBC in the Pacific Northwest, when a group of European and French Canadians laborers complained that the increase of wages of Native Hawai'ian Islander laborers from "merely food and cloathing [sic]" to $£ 17$ a year was too high. George Simpson cut the wages of Native Hawai'ians from $£ 17$ to $£ 10$ "which satisfies all parties" (Merk 1931:91). One might wonder if all parties were truly satisfied, but by the 1840s, wages of Native Hawai'ian Islanders roughly matched that of other employees (Emmons 1925:268, cf., Archives of Manitoba 1843 and Pipes 1931: 339-341). HBC elites certainly recorded clashes between ethnicities, but moments of developing community may not have been given as much weight in European accounts.

It is important to note that there were also factors that blurred ethnic divisions in the Village. Households within the Village were multi-ethnic, as many employees had Native American wives and metís children. Some of the Hawaiians and American Indian wives of 
employees were from high-status social categorizations in their homelands and some of the wives brought American Indian slaves to the household in spite of the British Slavery Abolition Act of 1833 (Wilson 2013, 2014).

Self-understanding and senses of belonging can differ from external categorization (Brubaker and Cooper 2000). Village inhabitants' identities may not have aligned with the HBC categories. Finally, the division between the classes of gentlemen vs. servant may have been more significant, given the disparity in things like pay and access to resources and locations (i.e. the stockade at night was off limits to most employees and their families). Belonging to the servant class could have been a uniting factor amongst the Village residents. Archaeological studies of the Village (Cromwell 2006; Holschuh 2013; Wynia 2013; Wilson 2014) find similarities in material culture and associated behavior between households, hinting at the development of shared cultural identity that crosscuts ethnic categories.

This examination of gastrolith distribution in recent Village excavations explores the nature of domesticated fowl consumption among the HBC labor force and their families. Considering the ethnic diversity of Village inhabitants, even within an ethnically-driven class structure, the widespread presence of gastroliths supports the concept of similarities in the production and consumption of domesticated fowl. Detailed analysis of Fort Vancouver U.S. Army-era foodways exists (Horton 2014), but to date, few authors have explicitly examined shared avian foodways within the fur trade context in the Pacific Northwest (e.g., Simons 1997, Hamilton 2000). Gastroliths collected during Public Archaeology Field Schools conducted by Portland State University, Washington State University Vancouver, and the National Park Service (NPS) from 2010-2014 are used here to examine patterns of domesticated fowl use across ethnic and socio-economic lines. Measurement of domesticated fowl production at Fort 
Vancouver provides a useful datum on the nature of adoption of western food traditions by fur trade families, many of which were composed of members from Pacific Northwest tribes for whom such foods would be more foreign. Prior to European contact, salmon was a cornerstone in native diets in the Pacific Northwest (Butler 2000:652-654; Butler and Campbell 2004). Native Northwest peoples also consumed a wide range of other fishes, pelagic and terrestrial vertebrates, mollusks and gastropods, and wild game birds (Butler 2000; Lyman et al. 2002; Butler and Campbell 2004; Bovy 2005; Campbell and Butler 2010:10-11). Though game birds did not provide the majority of animal foods, their incorporation into diets may have made domesticated fowl somewhat less exotic. Additionally, Native Hawaiian Islanders bred chickens prior to the incorporation of chickens in the Pacific Northwest (Kirch 2001; Kirch and O'Day 2003), but each of these groups had distinct approaches to preparing fowl for the table. The reported ethnic diversity in the Village created a rare environment to explore the archaeological remains of shared foodways, and a unique opportunity for archaeologists to address the navigation of identity under such circumstances.

\section{Gastroliths in Other Archaeological Contexts}

Gastroliths are small, hard objects (typically rocks) consumed by a variety of fauna including ducks (Anseriformes) and chickens (Galliformes) to aid in digestion, serving a function similar to teeth. Without gastroliths, the health of a bird is impacted through retaining fibrous material in its gizzard (Wings 2004:30). As gastroliths are abraded by stomach acid, they eventually become small enough to be passed (Wings 2004:52); thus, small gastroliths may end up in poultry yards through natural processes, while larger ones are removed from the gizzard during butchery. The period required to dissolve a gastrolith varies by fauna, but studies on modern Anseriformes indicates a maximum of 7.5 months (Bottema 1975:397). 
The digestive process creates gastroliths with very finely etched and polished surfaces not dissimilar to sea glass: a dull matte color, and subangular edges, particularly when the parent material is ceramic or glass (Bottema 1975; Cane 1982; Goode 2009). Unlike scratched ceramic and glass fragments, the surface is uniformly without luster. Some bird species select gastrolith materials by color, with a preference for lighter-colors (Bottema 1975:398; Cane 1982:26).

Gastroliths have been noted in both prehistoric and historical archaeological contexts (Cane 1982; Werth 1990; Lubinski and Burtchard 2005:43; Whitson 2013:43; Hill 2014). Archaeological and historical examination of duck and chicken gizzards have identified both ceramic (blue and white) sherds and glass gastroliths (Brown 1907:392; Bottema 1975:398; Goode 2009:13). Though there is some evidence for a correlation between bird size and gastrolith size at ingestion (Wings 2007:2), most authors note no clear connection, instead observing a general limit in the diameter of chicken and duck gastroliths at less than $15 \mathrm{~mm}$ (Bottema 1975:399; Cane 1982:26; Wings 2004:59; Goode 2009:1). These characteristics are reflected in gastroliths recovered archaeologically in the Fort Vancouver Village (Table 2).

Elsewhere there has been some debate as to whether artifacts identified as gastroliths are truly gastroliths, or if they are something else such as game pieces (Goode 2009). The distribution of these objects in the Village, the frequency of sizes smaller than $6 \mathrm{~mm}$, and the lack of archival evidence that games such as Mankala were played at Fort Vancouver increases the likelihood that they are gastroliths.

\section{Fowl in Fort Vancouver's Archival Records}

Wild fowl comprised a large part of Fort employees' diets prior to the arrival of cattle in 1836, and at least an occasional part of diets thereafter (Ballantyne 1879:58,106,109,115; 
Kingston 1923:168; Gibson 1985:40). Chief Factor John McLoughlin spearheaded local farming efforts partially because fixed trading posts such as Fort Vancouver often drove away or exterminated wild game (Hussey 1957b:1). Domesticated turkeys and chickens were initially imported to the Pacific Northwest in 1792 to Vancouver Island, and plans from 1818 at nearby Fort George (later renamed Fort Astoria) in Astoria, Oregon, identified poultry yards for a flock of chickens (Kingston 1923; Hussey 1976:257; Gibson 1985:15). After Fort George was acquired by the HBC through a merger with the Northwest Company in 1821, at least some of the Fort George chickens were relocated to Fort Vancouver (Horton 2010:10). Chickens were also brought to the Fort in 1825 by a party led by HBC Governor George Simpson (Gibson 1985:33).

Though not nearly as extensive as the documentation for domesticated mammals, records indicate that domestic fowl kept at Fort Vancouver included turkeys, pigeons, and chickens. Flocks varied from as many as 62 in 1828, to as few as nine in 1836 (Hussey 1972:169-170; Gibson 1985:37). However, villagers may have kept additional fowl that were not recorded by or the property of the HBC. An unnamed visitor observed in 1828 that Fort Vancouver included 'the usual domestic fowl" (Hussey 1957a:63; Hussey 1976:54), and in 1836, Narcissa Whitman visited the Fort Vancouver Farm and stated there were "hens, turkeys, pigeons, but no geese" (Whitman 1982:52).

\section{Faunal Remains from the Village}

Faunal assemblages from the Village field school excavations, and other previous data recovery excavations, include very few avian remains. The scarcity of avian remains is particularly noticeable when contrasted with the abundance of large mammal remains like cow (Bos taurus). When present, remains are typically in poor condition and frequently cannot be 
identified to species or even family levels. Other excavations near the Village have recovered chicken remains, but bone is often poorly preserved (Kardas 1971:260). Results from the test excavations for the Interstate 5- State Route 14 Highway revision (Operations 11, 13, and 25) reported only two identified fowl bones in their HBC strata assemblage. They noted "the great scarcity of fowl bones in the HBC strata, plus the complete absence of fish, is interesting. We know that the Company had domestic fowl such as chickens, turkeys and pigeons at some of its posts, and one would certainly expect the presence of at least wild fowl bones" (Chance and Chance 1976:257).

Likewise, Henry (1982:154) identified low numbers of fowl bones from Village area excavations in 1977. The assemblage contained a minimum number of individuals (MNI) of 11, established from a number of identified specimens (NISP) of 23. These remains were Anseriformes, including Anatidae, Common Goldeneye (Bucephala clangula) and Mallard (Anas platyrhynchos). The faunal remains were uncovered in large pit features (Features 105, 127, and 148) within a palisaded area identified as the HBC hospital (Operation 19). Interestingly, Henry (1982:156) comments on the absence of domesticated fowl: "Chicken and turkey may not have been used at the site at all, as neither is found in any $\mathrm{HBC}$ deposit." This assertion uses presence of faunal remains to directly determine animal use without accounting for poor avifaunal survivorship through taphonomic processes, or the notable difficulty in identifying incomplete avian elements (Reitz 1987).

Further evidence of issues with the faunal record as a direct measure of diet at Fort Vancouver is seen in the dearth of fish remains. Fish, and salmon in particular, played an important role in the diets of Fort Vancouver residents living outside the stockade as it formed a substantial part of their rations (Hussey 1991:286). However, an even smaller amount of 
osteichthyes remains has been recovered than that of avifauna (Kardas 1971: 278, 284; Chance and Chance 1976: 256-257; Henry 1982; Thomas and Hibbs 1984; Horton 2010).

In previous excavations at Fort Vancouver, avian remains have comprised a relatively small amount of any assemblage, and much of the previous work has focused on the NISP or the collective weight of bones over the MNI. Additionally, screening methods for older excavations likely impacted the retention of avifaunal remains. The NISP of recovered avifaunal as compared to other faunal remains (the brunt of which is identified as medium or large mammal, if not identified to finer taxa) highlights the importance of secondary data such as that provided by gastrolith analysis to support archival and faunal records.

The 1980 and 1981 Village excavations by Thomas and Hibbs illustrates the relative low frequency of fowl remains recovered archaeologically. Of the 2,942 bone fragments recovered from the John Johnson House (Operation 14), 55 were identified as bird (Thomas and Hibbs 1984:174). Other Village houses that were tested and contained avifaunal remains included a house site with no identifiable owner (Operation 55), where two bird bones (otherwise unidentified) were recovered out of 169 bone fragments total (Thomas and Hibbs 1984:606). At the Charlebois House Site (Operation 56), eight bird bones (otherwise unidentified) were recovered out of 363 total bone fragments (Thomas and Hibbs 1984:612). Finally, the William Kaulehelehe House (Operation 58) contained five bird bones, out of a total of 43 recovered bone fragments (Thomas and Hibbs 1984:629). Fourteen shell fragments from chickens were recovered from Operation 53, an area of intermittent use by seasonal employees and Native American traders, but of the bird bones recovered, only mallard (Anas sp.) was identified (Thomas and Hibbs 1984:478,526). Thomas and Hibbs (1984:526) suggest that "birds in general apparently were of minor importance and probably were taken during sport hunting." Likewise, 
in Operation 60, which Thomas and Hibbs inferred were camp sites of American Indian traders, transient employees (fur brigade members) or the wives and/or slaves of village men, five bird bones were recovered out of a total of 278 bone fragments (Thomas and Hibbs 1984:687).

Excavations within the "Kanaka House" (Operation 20A in Thomas and Hibbs 1984:312324)identified six extremely fragmented duck- or chicken-sized bird bone fragments $(0.24 \mathrm{~g})$, out of 172 bones recovered from that site.

Jabine's (1982:840) analysis of faunal remains from the 1981 Village excavations (Thomas and Hibbs 1984) determined that chicken/turkey within HBC-era deposits represented $3 \%$ of the NISP with mallard, wood duck, teal, and goose representing $12 \%$ of the assemblage. More recent archaeological testing for the Columbia River Crossing also found few HBC-context avifaunal remains (Horton 2010). The nearby Columbia River is home to numerous modern migratory birds including Common Merganser (Mergus merganser), Mallard (Anas platyrhynchos), and Canada Goose (Branta canadensis) (Grace 2009). It is likely that the recovered historical avifaunal remains are reflective of similar species.

Previously Recorded Ceramics at Fort Vancouver

The recorded 19th century archaeological deposits of HBC Fort Vancouver have been veritably defined by British, and to a lesser degree, Chinese ceramic wares. Ceramics are very common, usually comprising $25 \%$ or more of $\mathrm{HBC}$ archaeological assemblages. The great majority of these wares were manufactured by the Staffordshire, England based firm of Copeland \& Garrett/W.T. Copeland (Spode). It is not uncommon for transferprint Spode wares at Hudson's Bay Company sites to be over $75 \%$ of the ceramics in an archaeological recovered assemblage (Cromwell 2006). Altogether, a total of 80 patterns of under-glaze monochrome transfer-printed white earthenware have been identified in the Fort Vancouver archaeological collections (this 
includes sites inside and outside of the Fort Vancouver palisade). Of these, 64 are manufactured by the Spode, Copeland \& Garrett, or Copeland and Sons potteries, and the remaining 16 patterns were manufactured by other Staffordshire potteries. An additional 18 patterns are unidentified as to pattern name or manufacturer (Ross 1976a; Ross 1976b).

Other ceramic ware types recovered at Fort Vancouver include these other Staffordshire wares: undecorated whiteware, feather-edged ware, hand-decorated "sprig" or "cottage" ware, mochaware, bandedware, copper-colored lusterware, and engine turned wares. To a much lesser degree, there are also European (possibly British) decorated and undecorated soft-paste porcelain wares. Finally, approximately $5 \%$ of the remaining ceramic ware sherds recovered from 19 th century HBC Fort Vancouver archaeological deposits are Chinese manufactured underglaze cobalt blue on Celadon gray export porcelain wares (Ross 1976a; Cromwell 2006). No matter the origin of these wares, it is interesting to note that all of these ceramic wares were transported nearly halfway across the planet by sailing vessels to be traded and used at this ethnically-diverse entrepôt of the British fur trade.

Gastroliths recovered in the 2010-2014 excavations occasionally exhibited transferprint patterns. Such instances of identifiable transferprint patterns can more strongly link specific gastroliths to the manufacture dates of the ceramics, establishing a terminus post quem (TPQ) for fowl consumption. These data, alongside other temporally diagnostic information from associated deposits, provide both a more accurate range of fowl consumption dates within the Fort and stronger evidence that the fowl that consumed these ceramics were not migratory, but kept on-site. 
Methods and Materials

The 67 gastroliths included in this analys is were collected during the joint Portland State University, Washington State University Vancouver, and NPS Public Archaeology Field Schools from 2010-2014. The excavations tested five Village house sites, house yard areas, and intermittent areas between yards and houses comprising samples totaling $86 \mathrm{~m}^{2}$ and $87.2 \mathrm{~m}^{3}$ of the whole site area (Figure 2). Excavators screened sediment through nested 1/4 and 1/8 in. (6 and $3 \mathrm{~mm})$ screens. They also collected bulk samples from features and house floors for wet screening through $1 \mathrm{~mm}$ window screen mesh, allowing for collection of smaller gastroliths. Generally, one quarter of each HBC level was wet screened. The examined assemblage includes a total of 67 artifacts composed of ceramic or glass. These were identified as gastroliths based on the criteria presented above. Analysts examined the transferprinted ceramic gastroliths for evidence of recognizable decorative patterns, which was facilitated by the abundance of decorated Spode patterns at the site (Cromwell 2006). While Village residents may have intentionally procured stone gastroliths, or 'chicken grit', for domesticated fowl, the nature of field school excavations has generally precluded their identification and recovery.

Gastroliths from five house sites are included in this study. The occupants of three houses are unnamed in the documentary record, and are referred to here as: House 7, a previously unidentified house termed 'Block F House," and a probable house site at Operation 55, first identified in the early 1980 s by Thomas and Hibbs (1984). The other two house sites are the house of William Kaulehelehe, a Native Hawai'ian preacher, and the house site of a FrenchCanadian fur-trapper named Little Proulx (Table 1). 
All faunal remains (NISP=8,998) from the projects included in this study were examined, and any element comparing favorably to avian was subject to more detailed analysis. Faunal remains were analyzed through reference to Chamberlain (1943), Harvey et al. (1968), Hargrave (1972), Koch and Rossa (1973), Olsen (1979a; 1979b), and Oates et al. (2003), as well as the faunal comparative collections housed at Portland State University, which include both wild and domesticate specimens. The primary author conducted the faunal analysis.

Results of Gastrolith Analysis

Sixty-seven glass and ceramic gastroliths were examined, with 43 (64\%) identified as glass and $24(36 \%)$ ceramic (Table 2). A sample of the gastroliths can be seen in Figures 3 and 4. Of all gastroliths, $17.9 \%$ displayed minimal abrading, indicating a short ingestion time, and removed via butchery rather than passed naturally. Twenty-five percent of the total gastrolith assemblage was collected through bulk sampling and may not have been retained in 1/8 in. (3 $\mathrm{mm})$ mesh. These small gastroliths were likely naturally passed by birds. The decorative pattern of three ceramic gastroliths could be identified. One had a hand-painted cottageware pattern (ca. 1829-1860), a second displayed stippling very similar to Spode's (ca. 1837-1860) 'Lily" and "Italian" (ca. 1816-1860) patterns, and a third was likely a Spode "British Flowers" pattern (ca. 1829-1860).

Sixty-two of the gastroliths were recovered from house interiors and five were from house exteriors. Where specific house occupancies could be established, recorded ethnic background was Native Hawai'ian or French-Canadian. For other structures and areas, it is difficult to establish ethnic affiliations, as multiple families often shared spaces (Kardas 1971:214). The variability in excavation volume and sample area between the house sites preclude direct comparison of the frequency of gastroliths between households. For example, 
the two households with the most gastroliths - Little Proulx and William Kaulehelehe - were the most extensively excavated house sites (Table 1). An examination of the spatial distribution of gastroliths at these two house sites (Figures 5 and 6) showed an overall even distribution across each house's space with the exception of areas within and around hearths and pits. Around these features, upwards of six times as many gastroliths were recovered.

An additional twenty-three gastroliths were identified during analysis and were not included in this study. These gastroliths were excluded because they were either from non-HBCera deposits $(\mathrm{N}=7)$, or were found outside the Village site $(\mathrm{N}=16)$. Those from outside the Village were excavated in 2015 in an area to the southeast of the Stockade. This area contained three structures, including a cooper's shop operated by a number of coopers, one of which was a Native Hawai'ian Islander named Spun Yarn. The 16 gastroliths (14 glass and 2 ceramic) were recovered from interior and exterior contexts of house areas adjacent to the cooper's shop. These artifacts otherwise matched the gastroliths previously described, with two exceptions: first, the only instance of a darkly-colored gastrolith (dark olive vessel glass), and second, the only instance of the "Macaw" or "Pagoda" ceramic pattern on a gastrolith (Copeland \& Garrett, ca. $1838-1860)$.

Results of Faunal Analysis

A total of 55 avian remains were identified from the faunal assemblages in the 2010-2014 field school excavations. Of these remains, 12 were identified to the level of Anseriformes. Burning and poor preservation made it difficult to establish species- or family-level taxonomic identifications. All non-intrusive avian elements identified for this project compared favorably with wild Anseriformes (e.g., ducks) but could not be identified to a finer taxonomic level. As 
with other notable Village excavations (Kardas 1971; Chance and Chance 1976; Henry 1982; Thomas and Hibbs 1984), no remains could be identified as domesticated bird.

Discussion

Archaeological studies do not commonly consider gastroliths. In historical sites where domesticated birds consume ceramics and glass, archaeologists may overlook or misidentify them. Reports on previous excavations at Fort Vancouver do not mention gastroliths, and without a re-examination of the assemblages it remains unknown whether these excavations uncovered gastroliths. At sites with poor bone preservation, gastroliths can be an important marker of fowl in past diets. Gastroliths from the Village provide a line of evidence for the presence of domesticated fowl, and also for shared dietary habits amongst houses likely to contain peoples representing diverse ethnic identities.

A review of previous excavations in the Village (Kardas 1971; Chance and Chance 1976; Henry 1982; Thomas and Hibbs 1984) finds sparse archaeological faunal evidence of fowl consumption by Village inhabitants. While fowl bones are present, they generally have a low NISP, and are primarily wild species. Domesticates such as chickens, turkeys, and pigeons are not common in the assemblages, and none were identified from the 2010-2014 faunal remains. A similar lack of fowl bones in faunal collections is present at the fur trade site of Fort Nisqually. Bird bones make up only about one percent of the collection by NISP, including wild waterfowl (Stilson 1991:16-23). Stilson further suggests that the absence of identifiable chicken bones and eggshells suggests "they were not on employees' menus" (1991:23). The fragmentary nature and poor state of preservation complicates drawing dietary conclusions from the faunal evidence.

Other researchers, like Cane (1982:31) and Lubinski and Burtchard (2005:43), note that gastroliths may be used as secondary evidence for avifauna that are otherwise absent in the 
archaeological record. The presence of some Galliformes remains from previous Village excavations strengthens evidence that the gastroliths in this study are related to fowl consumption. A direct correlation between gastroliths and avian species is unfortunately difficult to establish.

While the imperfect faunal evidence from prior Village excavations supports both wild migratory waterfowl (primarily ducks and geese) and domesticated fowl (chickens and turkeys), it is unlikely that wild fowl are responsible for the gastroliths. First, wild fowl are unlikely to have consumed glass and ceramic fragments consistently off-site. Outside of the Fort setting, there was a low population density of colonial settlers, and few (essentially non-existent) opportunities for wild fowl to consume transferprinted ceramics. Therefore while migratory birds have great ranges, it is unlikely that migrating wild fowl consumed the ceramics off-site and then were butchered in the Village. It is equally unlikely that flocking migratory birds that landed in the Village could consume ceramic and glass fragments in the areas around the houses without being shot for food. Even if one did consume a fragment, it would take months for an identifiable ceramic or glass gastrolith to form in a wild bird's gizzard. Thus, it is improbable that the glass and ceramic gastroliths recovered from the Village are from wild fowl.

The spatial distribution of gastroliths can also indicate behaviors associated with butchery, refuse disposal, and where fowl were kept. Small gastroliths found outside Village structures were likely normally passed, while larger gastroliths, or those showing less abrasion, may have been discarded into the yard after bird butchery. The percentage found in matrix wetscreened through $1 \mathrm{~mm}$ mesh illustrates the necessity of bulk sampling. If these smaller gastroliths likely entered the archaeological record naturally and not through butchery, they can indicate areas in which domesticated fowl were kept and raised. This would also provide a better 
argument against a 'game pieces' interpretation due to their small size. Gastroliths found inside Village houses may be explained by the apparent practice of indoor animal butchery. In an 1834 visit to the Village, Hall J. Kelley described a cabin that "having been long a place for dressing fish and wild game, was extremely filthy. The black mud about the doors $[\ldots]$ was abundantly mixed with animal putrescence" (1834:181).

Diet can be a significant marker of cultural behavior in past communities. Highly segregated ethnic and social communities are often characterized by distinct patterns of faunal remains. For example, Hamilton (2000:260) notes that at Nottingham House (occupied 18021806), gentlemen's bone refuse is characterized by relatively high frequencies of mammalian and avian species, and laborer's quarters are dominated by fish bones. It is unsurprising that such distinct patterns blur on a more communal landscape. According the written record, the Village was an ethnically diverse population, but evidence suggests at least some level of shared behaviors and an integrated community (Cromwell 2006; Wynia 2013). The presence of ceramic and glass gastroliths amongst households indicates a common diet of domesticated fowl. While there is very little known about household production of food, including either the procurement of wild avifauna and the keeping of domesticated fowl, the presence of gastroliths in varied contexts across the Village landscape suggest that households with varied ethnic categorizations may have been at least sharing similar domestic fowl production as well as consumption.

Shared production and consumption of domesticated fowl provide an important piece of evidence in interpreting the social identities of HBC laborers and their families. The two most intensively sampled households, that of William Kaulehelehe and Little Proulx, were documented to contain people of divergent ethnic categories (Native Hawaiian in the former, and French Canadian and Chinookan in the latter) but both contained numerous gastroliths 
suggesting similar patterns in production and consumption of domesticated fowl. The hierarchical British colonial system constantly reinforced their ethnic categorization. Particularly when conflict was both driven by HBC class structure, and recorded by the HBC, instances of shared foods (if not necessarily foodways, as we have limited evidence from gastroliths) have broad implications for helping to define the sense of belonging and self within the pluralistic community. While we cannot address variability in prescribed methods of butchering, preparing, and consuming avifauna between houses that could reflect ethnicity, the similarities in gastrolith evidence provides at least a null hypothesis with which to explore further differences that may be tied to the perceived identity and status of householders.

\section{Conclusion}

Gastroliths recovered from Fort Vancouver's Village are first used to strengthen evidence of domesticated fowl consumption, and second to examine the distribution of domesticated fowl consumption across a landscape of diverse ethnic and class social relations. Faunal recovery from fur trade posts infrequently includes substantive avifaunal remains. Previous interpretations of the faunal record have used this absence to characterize the importance of both domesticated and wild fowl in diets by either placing more weight on the latter, or eliminating fowl as anything but an opportunistic and irregular food source. Analysis of gastroliths, coupled with archival research, provides an alternative measure of the use and adoption of domesticated fowl. This is particularly useful in archaeological sites where most recovered avifaunal remains compare favorably to only wild fowl, despite records of domesticated birds being kept on-site.

The use and/or adoption of domesticated species may be linked to concepts of identity and social class. At Fort Vancouver, the use of domesticated fowl appears to cross-cut HBCimplemented class and ethnic categories. Other archaeological work at the site supports the 
phenomena of social activities cross-cutting ethnic and class distinctions (Cromwell 2006; Dorset 2012; Holschuh 2013; Wynia 2013). Such evidence provides nuances in the frontier narrative when taken alongside examples of Village conflict promoted by ethnic categories and class, as with the French Canadian wage complaints noted earlier.

Inside the eclectic mix of structures that comprised the Village, HBC policy at least partially shaped identity. The necessity of communal living, glocalization on the frontier, and the integration of European, North American, American Indian, and Pacific cultures into pre-existing definitions of identity also entangled their sense of self. Each person who arrived at the Village had some defined identity, whether or not it fit neatly into the prescribed identity set by British colonialism. Some laborers married Native American women and had children (Kardas 1971), further entangling distinct boundaries between ethnic classes. It is not clear if fowl keeping was gendered, as other fur trade activities were, but it may have been. Further, there is no evidence from the historical record that the $\mathrm{HBC}$ authorities specifically encouraged the production of domestic fowl as a means to increase food independence of families under its care. It is possible that this was the case, and lacking useful documentary information it is unclear how live fowl became part of the Village subsistence patterns. It does not appear that the HBC sold them at the company store (or "Sale Shop").

While it is likely that people that lived in the Village continued to keep and use domesticated fowl after they left, the very different places where they wound up after the demise of fur trade Fort Vancouver argues against hybridity (see also Silliman 2015). Likewise, concepts of ethnogenesis and creolization which have been used to model shared practices of pluralistic communities (Dawdy 2000; Voss 2008; Hu 2013; Weik 2014; see Nassaney this volume) do not fit the history of the Village for the same reasons. The residents of the Village, 
perhaps because of the punctuated nature of the transition from fur trade to American immigration did not form a distinctive ethnic identity like the Metís of Canada. The people of the Village were dispersed to many places and became parts of new communities, some related to HBC colonial activities, some indigenous, and some American. In this sense, the observed patterning appears more like practical politics (Silliman 2001). Acts of residence conducted by the people who lived in the Village may have mediated differences between them that colonial powers had in part defined and even accentuated. Shared practices may have created some sense of fur trade community, supporting peaceful relations, perhaps securing food stability, while allowing for the maintenance of unique ethnic social identities.

Opening a "window" on avifauna production and use in the pluralistic Fort Vancouver community using ceramic and glass gastroliths permits us to begin to explore precontact, early contact, and post contact periods tied to the transformation of food traditions (Panich 2013). Fort Vancouver's place is central and intermediary to this narrative. Many of the American Indian and metís families (including some families with Native Hawaiian men) of Fort Vancouver were relocated to reservations during the early American colonial period (Deur 2012; Wilson 2014). Likewise, some residents retreated with the $\mathrm{HBC}$ to Victoria and other places in Canada, including some (but not all) of the Native Hawaiian population (Barman 1995; Deur 2012). Some of the HBC employees and their families became part of American settlement in Oregon Territory. Therefore, understanding the fur-trade era use of domesticated fowl and other practices of the people of the Fort Vancouver Village yields important historical data that are relevant to modern indigenous groups, Native Hawaiians interested in the Hawaiian diaspora, and American families whose heritage parallels both American and fur trade immigration periods. 
Diverse communities like those at Fort Vancouver's Village are increasingly seen not through binary labels and simple histories, but by rich narratives that place importance on the nuances and complications of frontier life. By incorporating multiple lines of evidence, archaeologists become better poised to understand how this complexity framed ethnicity and class on the frontier. 


\section{Acknowledgments}

Thanks are due to Dr. Virginia L. Butler, Dr. Beth Horton, Dr. Kristine M. Bovy, Dr. Michael Etnier, John Edwards, National Park Service and Fort Vancouver National Historic Site, Washington State University Vancouver, Portland State University, the Oregon Archaeological Society, Matthew Munsinger, and Fort Vancouver Archaeology Lab Volunteers In Parks, interns, and Public Archaeology Field School students.

References

Archives of Manitoba

1843 Columbia District Establishment - Outfit 1843. Location Code: B.223/g/8. Winnipeg, Canada.

Ballantyne, Robert Michael.

1879 Hudson Bay; Or, Everyday Life in the Wilds of North America. Reprinted . Kraus Reprint Co., New York, NY.

Barman, Jean

1995 New Land, New Lives: Hawaiian Settlement in British Columbia. The Hawaiian Journal of History 29: 1-32.

Bottema, S.

1975 The Use of Gastroliths in Archaeology. In Archaeozoological Studies, A. T. Clason, editor, pp. 397-406. North-Holland Publishing Co., Amsterdam.

Bourdieu, Pierre

1977 Outline of a Theory of Practice. Cambridge University Press, Cambridge.

Bovy, Kristine M.

2005 Effects of Human Hunting, Climate Change, and Tectonic Events on Water Birds along the 
Pacific Northwest Coast during the Late Holocene. Doctoral dissertation, Department of Anthropology, University of Washington. University Microfilms International, Ann Arbor, MI. Brown, Barnum

1907 Gastroliths. Science, New Series 25(636):392-392.

Brubaker, Roger and Frederick Cooper

2000 Beyond "Identity." Theory and Society 29(1):1-47.

Burley, Edith I.

1997 Servants of the Honourable Company: Work, Discipline, and Conflict in the Hudson's Bay Company, 1770-1870. Oxford University Press, Toronto.

Butler, Virginia L.

2000 Resource Depression on the Northwest Coast of North America. Antiquity 74:649-661.

Butler, Virginia L., and Sarah K. Campbell

2004 Resource Intensification and Resource Depression in the Pacific Northwest of North America: A Zooarchaeological Review. Journal of World Prehistory 18(4):327-405.

Butler, Virgina L., and Michael L. Martin

2013 Aboriginal Fisheries of the Lower Columbia River. In Chinookan Peoples of the Lower Columbia, Robert T. Boyd, Kenneth M. Ames, and Tony A. Johnson, editors, pp. 80-105. University of Washington Press, Seattle.

Campbell, Sarah K, and Virginia L Butler

2010 Archaeological Evidence for Resilience of Pacific Northwest Salmon Populations and the Socioecological System over the Last 7,500 Years. Ecology and Society 15(1):1-20.

Cane, Scott

1982 Bustard Gastroliths in the Archaeological Record. Australian Archaeology 14:25-34. 
Chamberlain, Frank Wilbut

1943 Atlas of Avian Anatomy. Michigan State College, East Lansing.

Chance, David H., and Jennifer V. Chance

1976 Kanaka Village/Vancouver Barracks 1974. Office of Public Archaeology Reports in Highway Archaeology No. 3. University of Washington, Seattle.

Cheek, Charles D.

1998 Massachusetts Bay Foodways: Regional and Class Influences. Historical Archaeology 32(3):153-172.

Cromwell, Robert J.

2006 "Where Ornament and Function Are so Agreeably Combined": Consumer Choice Studies of English Ceramic Wares at Hudson's Bay Company Fort Vancouver. Doctoral dissertation, Department of Anthropology, Syracuse University. University Microfilms International, Ann Arbor, MI.

Deagan, Kathleen A.

2008 Environmental Archaeology and Historical Archaeology. In Case Studies in Environmental Archaeology: Interdisciplinary Contributions to Archaeology, Elizabeth J. Reitz, Sylvia J.

Scudder, and Margaret C. Scarry, editors, pp. 21-42. Springer, New York.

Deur, Douglas

2012 An Ethnohistorical Overview of Groups with Ties to Fort Vancouver National Historic Site. Northwest Cultural Resources Institute Report No. 15. Fort Vancouver National Historic

Site, National Park Service, Vancouver, Washington.

Dorset, Elaine C.

2012 A Historical and Archaeological Study of the Nineteenth Century Hudson's Bay Company 
Garden at Fort Vancouver: Focusing on Archaeological Field Methods and Microbotanical Analysis. Master's thesis, Department of Anthropology, Portland State University, WA.

Dawdy, Shannon Lee (editor)

2000 Creolization. Historical Archaeology 34.

Emmons, George Thornton

1925 Extracts from the Emmons Journal. Oregon Historical Quarterly 26(3): 263- 273.

Erigero, Patricia C.

1992 Cultural Landscape Report: Fort Vancouver National Historic Site, Volume II. National Park Service, Pacific Northwest Region, Seattle, WA.

Fernandez-Armesto, Felipe

2002 Near a Thousand Tables: A History of Food. The Free Press, New York, NY.

Gibson, James R.

1985 Framing the Frontier: The Agricultural Opening of the Oregon County 1786-1846.

University of Washington Press, Seattle.

Giddens, Anthony

1984 The Constitution of Society. University of California Press, Berkeley.

Goode, Charles

2009 Gizzard Stones or Game Pieces? African Diaspora Archaeology Newsletter 12(1):1-23.

Grace, Lisa

2009 Vertebrate and Vascular Plant Inventories for Fort Vancouver National Historic Site: NPS Species Certified Lists. Natural Resource Technical Report NPS/NCCN/NRTR-2009/001. Fort Collins, CO.

Hamilton, Scott 
2000 Dynamics of Social Complexity in Early Nineteenth-Century British Fur Trade Posts. International Journal of Historical Archaeology 4(3):217-270.

Hargrave, Lyndon L.

1972 Comparative Osteolgy of the Chicken and American Grouse. Prescott College Press, Prescott.

Harvey, Elmer B., H. E. Kaiser, and L. E. Rosenberg

1968 An Atlas of the Domestic Turkey (Meleagris Gallopavo) Myology and Osteology. U.S.

Atomic Energy Commission, Division of Biology and Medicine, Washington, DC.

Henry, Craig

1982 Fauna in HBC Kanaka Village/Vancouver Barracks 1977. Caroline D. Carley, editor.

Office of Public Archaeology Reports in Highway Archaeology No. 3. University of

Washington, Seattle.

Hill, Cayla L.

2014 The Expansion of Catholicism: An Exploration of St. Joseph's College, the First Catholic Boarding School for Boys within the Oregon Territory. Master's Thesis, Department of Anthropology, Oregon State University, Corvallis.

Holschuh, Dana Lynn

2013 An Archaeology of Capitalism: Exploring Ideology through Ceramics from the Fort Vancouver and Village Sites. Master's Thesis, Department of Anthropology, Portland State University, Portland, OR.

Horton, Elizabeth A.

2010 Appendix III: Faunal Analysis. In Results of National Park Service Archaeological Testing on the Vancouver National Historic Reserve for the CRC Project, Leslie M. O'Rourke, Todd A. 
Miles, and Douglas C. Wilson. Northwest Cultural Resources Institute Report No. 8. Fort Vancouver National Historic Site, National Park Service, Vancouver, WA. 2014 Space, Status, and Interaction: Multiscalar Analyses of Officers, Soldiers, and Laundresses at 19th-Century Fort Vancouver, Washington. Doctoral dissertation, Department of Anthropology, Washington State University. University Microfilms International, Ann Arbor, MI.

$\mathrm{Hu}, \mathrm{Di}$

2013 Approaches to the Archaeology of Ethnogenesis: Past and Emergent Perspectives. Journal of Archaeological Research 21:371-402.

Hussey, John A.

1957a The History of Fort Vancouver and Its Physical Structure. Abbott, Kerns \& Bell, Portland, OR.

1957b The Fort Vancouver Farm. Manuscript, Fort Vancouver National Historic Site, National Park Service, Vancouver, WA.

1972 Historic Structures Report, Historical Data, Vol. 1. Fort Vancouver National Historic Site and National Park Service, Washington D.C.

1976 Historic Structures Report, Historical Data, Vol. 2. Fort Vancouver National Historic Site and National Park Service, Washington D.C.

1991 The Women of Fort Vancouver. Oregon Historical Quarterly 92(3): 265-308.

Jabine, Anne

1982 Appendix D: Pre-1860 Faunal Assemblages at Kanaka Village/Vancouver Barracks. In Report of Investigations of Excavations at Kanaka Village/Vancouver Barracks, Washington, 1980/1981, Bryn Thomas and Charles Jr. Hibbs, editors, pp. 835-849. Report to Washington 
State Department of Transportation, Olympia, from Archaeological and Historical Services, Eastern Washington University, Cheney, WA.

Janowitz, Meta F.

1993 Indian Corn and Dutch Pots: Seventeenth-Century Foodways in New Amsterdam/New York. Historical Archaeology 27(2):6-24.

Kardas, Susan

1971 "The People Who Bought This and the Clatsop Became Rich.” A View of Nineteenth Century Fur Trade Relationships on the Lower Columbia Between Chinookan Speakers, Whites, and Kanakas. Doctoral dissertation, Department of Anthropology, Bryn Mawr College, Ann Arbor, MI.

Kelley, Hall J.

1834 Hall J. Kelley on Oregon. Fred Powell, editor. Reprint 1. DaCapo Press, New York. Kingston, C.S.

1923 Introduction of Cattle into the Pacific Northwest. Washington Historical Quarterly 14(3):163-185.

Kirch, P. V.

2001 Polynesian feasting in ethnohistoric, ethnographic, and archaeological contexts: a comparison of three societies. In Feasts: Archaeological and Ethnographic Perspectives on Food, Politics, and Power, M. Dietler and B. Hayden, editors, pp. 168-184. Smithsonian Institution Press, Washington, DC.

Kirch, Patrick, and Sharyn Jones O'Day 2003 New archaeological insights into food and status: a case study from pre-contact Hawaii. World Archaeology 34(3): 484-497. 
Koch, Tankred, and Erwin Rossa

1973 Anatomy of the Chicken and Domestic Birds, Bernard H. Skold and Louis DeVries, translators. Iowa State University Press, Ames.

Lightfoot, Kent G.

2006 Missions, Furs, Gold, and Manifest Destiny: Rethinking an Archaeology of Colonialism for Western North America. In Historical Archaeology, Martin Hall and Stephen W. Silliman, editors, pp. 272-292. Blackwell, Maldon, MA.

Lightfoot, Kent G., Antoinette Martinez, and Ann M. Schiff

1998 Daily Practice and Material Culture in Pluralistic Social Settings: An Archaeological

Study of Culture Change and Persistence from Fort Ross, California. American Antiquity 63(2):

$199-222$.

Lubinski, Patrick M., and Greg C. Burtchard

2005 Fryingpan Rockshelter (45PI43): A Subalpine Fauna in Mount Rainier National Park.

Archaeology in Washington 11:35-52.

Lyman, Lee R., Judith L. Harpole, Christyann M. Darwent, and Robert Church

2002 Prehistoric Occurrence of Pinnipeds in the Lower Columbia River. Northwestern Naturalist $83: 1-6$.

Merk, Frederick

1931 Fur Trade and Empire: George Simpson's Journal. Harvard University Press, Cambridge. Mullaley, Meredith J.

2011 Rebuilding the Architectural History of the Fort Vancouver Village. Master's Thesis, Department of Anthropology, Portland State University, Portland, OR.

Nassaney, Michael S. 
2015 The Archaeology of the North American Fur Trade. University of Florida Press, Gainesville.

Oates, David W., D. Ed Boyd, and Jennifer S. Ramaekers

2003 Identification of Waterfowl Breastbones and Avian Osteology (sterna) of North American Anseriformes. Special Publication, Virginia Museum of Natural History, Lincoln.

Ortner, Sherry B.

2006 Anthropology and Social Theory. Duke University Press, Durham, NC.

Olsen, Stanley John

1979a Osteology for the Archaeologist: North American Birds: Skulls and Mandibles. Peabody

Museum of Archaeology and Ethnology, Harvard University 56(4): 50-89.

1979b Osteology for the Archaeologist: North American Birds: Postcranial Skeletons. Peabody Museum of Archaeology and Ethnology, Harvard University 56(5):92-186.

Panich, Lee M. 2013 Archaeologies of Persistence: Reconsidering the Legacies of Colonialism in Native North America. American Antiquity 78(1): 105-122.

Pavao-Zuckerman, Barnet

2007 Deerskins and Domesticates: Creek Subsistence and Economic Strategies in the Historic Period. American Antiquity 72(1):5-33.

Pipes, Nellie B.

1931 Indian Conditions in 1836-38. Oregon Historical Quarterly 32(4): 332-342.

Reitz, Elizabeth J.

1987 Vertebrate Fauna and Socioeconomic Status. In Consumer Choice in Historical

Archaeology, Suzanne M. Spencer-Wood, editor, pp. 101-119. Plenum Press, New York.

Rogers, Donnell J. 
$1993 \mathrm{Ku}$ on the Columbia: Hawaiian Laborers in the Pacific Northwest Fur Industry. Master's thesis, Interdisciplinary Studies, Oregon State University, Corvallis.

Ross, Lester A.

1976a Fort Vancouver 1829-1860: A Historical Archaeological Investigation of the Goods Imported and Manufactured by the Hudson's Bay Company. Manuscript, Fort Vancouver National Historic Site, National Park Service, Vancouver, WA.

1976b Fort Vancouver Archaeological Report 1829-1860. Vancouver, WA.

Roulstone, Thomas B.

1975 A Social History of Fort Vancouver 1829-1849. Master's Thesis, Department of History, Utah State University, Logan.

Silliman, Stephen

2001 Agency, practical politics and the archaeology of culture contact. Journal of Social Archaeology 1(2): 190-209.

2015 A Requiem for Hybridity? The Problem with Frankensteins, puréees, and mules. Journal of Social Archaeology 15(3): 277-298.

Simmons, Stephanie Catherine

2014 Exploring Colonization and Ethnogenesis through an Analysis of the Flaked Glass Tools of the Lower Columbia Chinookans and Fur Traders. Master's Thesis, Department of Anthropology, Portland State University, Portland, OR.

Simons, D. D.

1997 Bird Remains from the Fort Ross Beach and Native Alaskan Village Sites. In The Native Alaskan Neighborhood: A Multiethnic Community at Colony Ross, K. G. Lightfoot, A. M. Schiff, and T. A. Wake, editors, pp. 310-318. The Archaeology and Ethnohistory of Fort Ross, 
California, vol. 2. Archaeological Research Facility, University of California, Berkeley.

Stilson, Leland M.

1991 A Data Recovery Study of 45-PI-405, the 1843 Fort Nisqually Village at Northwest

Landing, Pierce County, Washington. Report to Weyerhaeuser Real Estate Company. Land

Management Division. from Western Heritage, Inc. Olympia, WA.

Thomas, Bryn, and Charles Hibbs, Jr.

1984 Report of Investigations of Excavations at Kanaka Village/Vancouver Barracks,

Washington, 1980/1981. Report to Washington State Department of Transportation, Olympia,

from Archaeological and Historical Services, Eastern Washington University, Cheney, WA.

Tveskov, Mark A.

2007 Social Identity and Culture Change on the Southern Northwest Coast. American

Anthropologist 109(3): 431-441.

Vibert, Elizabeth

2010 The Contours of Everyday Life: Food and Identity in the Plateau Fur Trade. In Gathering

Places: Aboriginal and Fur Trade Histories, Carolyn Podruchny and Laura Peers, editors, pp.

119-148. UBC Press, Vancouver.

Voss, Barbara L.

2005 From Casta to Californio: Social Identity and the Archaeology of Culture Contact. American Anthropologist 107(3):461-474.

2008 The Archaeology of Ethnogenesis: Race and Sexuality in Colonial San Francisco.

University of California Press, Berkeley.

Warner, Mikell de Lore Wormell, and Harriet Duncan Munnick

1972 Catholic Church Records of the Pacific Northwest: Vancouver, Volumes I \& II, and 
Stellamaris Mission. French Prairie Press, St. Paul, OR.

Weik, T. M.

2014 The Archaeology of Ethnogenesis. Annual Reviews of Anthropology 43: 291-305.

Werth, Dennis

1990 Gizzard Stones: The Placement and Distribution of Bird Gastroliths as Evidence of

Prehistoric Hunting of Upland Game Birds. In The Posy Archaeology Project, Upland Use of the

Central Cascades, Mt. Hood National Forest, Greg C. Burtchard, editor, pp. 159-167. Report to

USDA Forest Service, Gresham, Oregon, from Laboratory of Archaeology and Anthropology,

Portland State University. Portland, OR.

Whitman, Narcissa

1982 My Journal, 1836. Lawrence Dodd, editor. Ye Galleon Press, Fairfield, WA.

Whitson, Erin Nicole

2013 Identifying with the Help: An Examination of Class, Ethnicity and Gender on a Post-

Colonial French Houselot. Master's thesis, Department of Sociology and Anthropology, Illinois

State University.

Wilson, Douglas C.

2013 Hawaiian Identity in the Pacific Northwest at Fort Vancouver. The Federalist Newsletter 36(2): 6-8.

2014 The Decline and Fall of the Hudson's Bay Company Village at Fort Vancouver. In Alis

Volat Propriis: Tales from the Oregon Territory 1848-1859, Chelsea Rose and Mark Tveskov, editors, pp. 21-42. Association of Oregon Archaeologists Occasional Paper Series No. 9.

Eugene, OR.

2015 A Mongrel Crowd of Canadians, Kanakas and Indians: The United States National Park 
Service Public Archaeology Programme and Fort Vancouver's Village. Journal of Community Archaeology \& Heritage 2(3):221-237.

Wilson, Douglas C., Kenneth M. Ames, and Cameron M. Smith

2017 Contextualizing the Chinook at Contact: The Middle Village. In Frontiers of Colonialism,

Christine D. Beaule, editor, pp. . University Press of Florida, Gainesville.

Wilson, Douglas C., and Theresa E. Langford

2011 Exploring Fort Vancouver. University of Washington Press, Seattle.

Wings, Oliver

2004 Identification, Distribution, and Function of Gastroliths in Dinosaurs and Extant Birds with Emphasis on Ostriches (Struthio Camelus). Doctoral thesis, The University of Bonn, Bonn, Germany.

2007 A Review of Gastrolith Function with Implications for Fossil Vertebrates and a Revised Classification. Acta Palaeontological Polonica 52(1):1-16.

Wynia, Katie Ann

2013 The Spatial Distribution of Tobacco Pipe Fragments at the Hudson's Bay Company Fort Vancouver Village Site: Smoking as a Shared and Social Practice. Master's Thesis, Department of Anthropology, Portland State University, Portland, OR. 
Figure Captions

FIGURE 1. Location of Fort Vancouver and Study Area (Kanaka Village). (Map by Katie A. Wynia, 2015.)

FIGURE 2. Location of Village Houses Examined for Gastroliths. OP denotes Operation. (Map by Katie A. Wynia, 2015.)

FIGURE 3. Sample of glass gastroliths. (John Edwards and Emily C. Taber, 2015.)

FIGURE 4. Sample of ceramic gastroliths from Village contexts. (John Edwards and Emily C. Taber, 2015.)

FIGURE 5. Distribution of Gastroliths in the Little Proulx House Site. (Map by Katie A. Wynia, 2015.)

FIGURE 6. Distribution of Gastroliths in the William Kaulehelehe House Site Excavation. (Map by Katie A. Wynia, 2015.) 
Tables

TABLE 1

EXCAVATION CONTEXTS OF EXAMINED GASTROLITHS

\begin{tabular}{|c|c|c|c|c|c|}
\hline $\begin{array}{l}\text { Accession } \\
\text { Number }\end{array}$ & Block & Interpretation & $\begin{array}{l}\text { Inferred Ethnic } \\
\text { Affiliation(s) of } \\
\text { Employee }\end{array}$ & $\begin{array}{r}\text { Area } \\
\text { Excavated } \\
\left(\mathrm{m}^{2}\right)\end{array}$ & $\begin{array}{r}\text { Gastrolith } \\
\text { Count }\end{array}$ \\
\hline 3120 & $\mathrm{~A}$ & House 7 & Hawaïan $^{1}$ & 8.0 & 2 \\
\hline $3120 / 3164$ & $\mathrm{C}$ & Open area & N/A & 7.0 & 4 \\
\hline 3164 & $\mathrm{~F}$ & Block F House & Hawaïan $^{1}$ & 4.0 & 1 \\
\hline 3164 & $\mathrm{~J}$ & Yard & Unknown & 13.8 & 1 \\
\hline $3184 / 3218 / 3248$ & $\mathrm{~L}$ & Little Proulx & $\begin{array}{l}\text { French Canadian/ } \\
\text { Chinookan }\end{array}$ & 38.1 & 41 \\
\hline 3184 & M & House (OP 55) & French Canadian $^{1}$ & 2.0 & 2 \\
\hline 3218 & $\mathrm{~K}$ & $\begin{array}{l}\text { William } \\
\text { Kaulehelehe }\end{array}$ & Hawaïan & 5.0 & 16 \\
\hline
\end{tabular}

Notes: ${ }^{1}$ Ethnic affiliation is unconfirmed in archival documents. 
TABLE 2

MATERIAL AND SIZE DISTRIBUTION OF GASTROLITHS EXAMINED FROM THE

VILLAGE

\begin{tabular}{lcccc}
\hline Material Type & \multicolumn{2}{c}{ Size } & Total \\
\hline COTTAGEWARE & $<6 \mathrm{~mm}$ & $6-10 \mathrm{~mm}$ & $10.1-15 \mathrm{~mm}$ & 1 \\
UNDECORATED & 1 & - & - & 6 \\
EARTHENWARE & - & 4 & 2 & \\
GLASS & & & - & 33 \\
$\quad$ COLORLESS & 21 & 12 & - & 5 \\
$\quad$ AQUA & 4 & 1 & - & 5 \\
$\quad$ LIGHT OLIVE & - & 5 & - & 1 \\
CHINESE PORCELAIN & & & - & 1 \\
$\quad$ WHITE AND BLUE EXPORT & - & 1 & & 12 \\
$\quad$ WHITE WITH ENAMEL & - & 1 & - & 3 \\
TRANSFER-PRINT & & & - & $\mathbf{6 7}$ \\
$\quad$ BLUE & - & 12 & $\mathbf{2}$ \\
$\quad$ RED & 1 & 2 & & \\
TOTAL & $\mathbf{2 7}$ & $\mathbf{3 8}$ & & \\
\hline
\end{tabular}


Figures

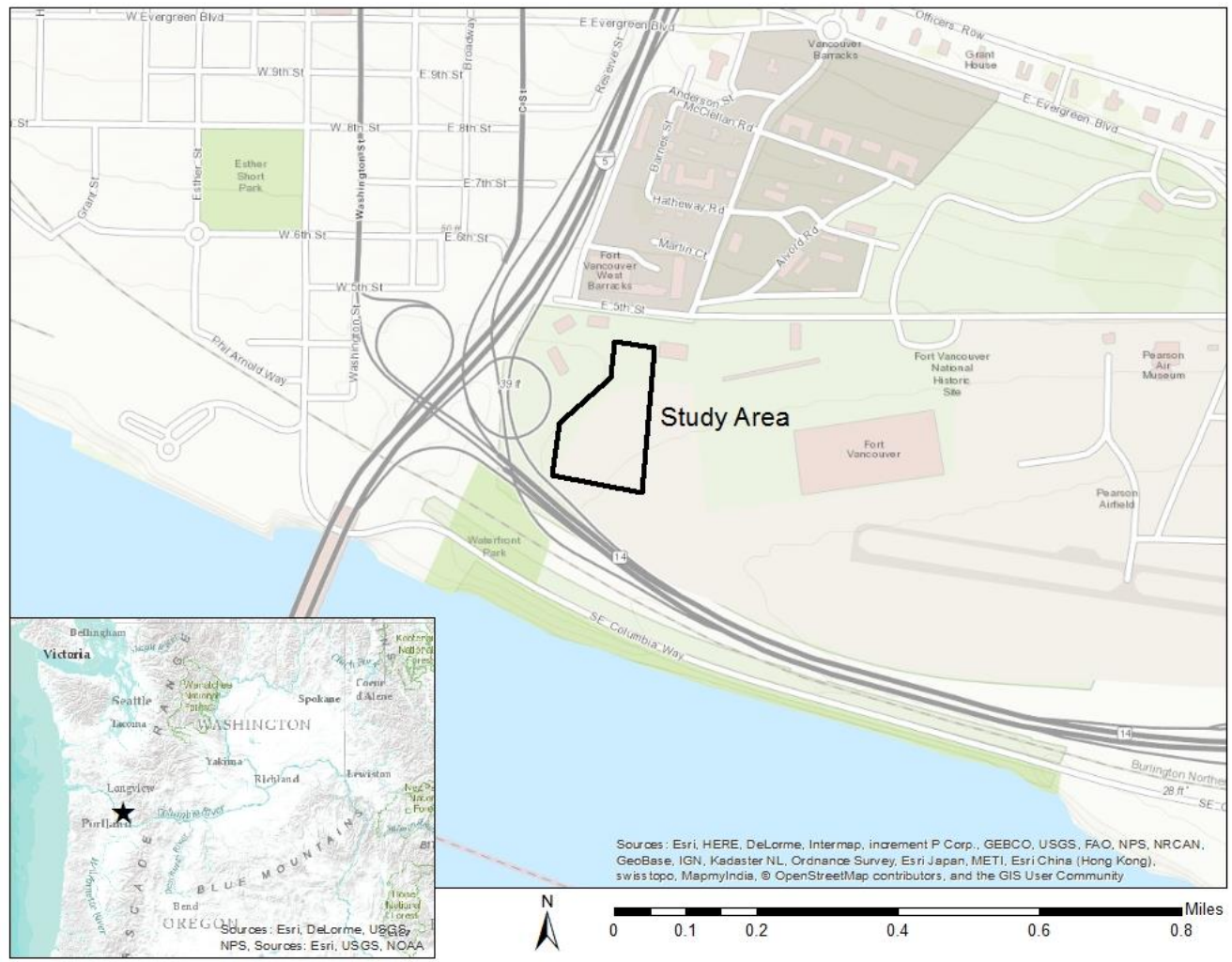

FIGURE 1. 


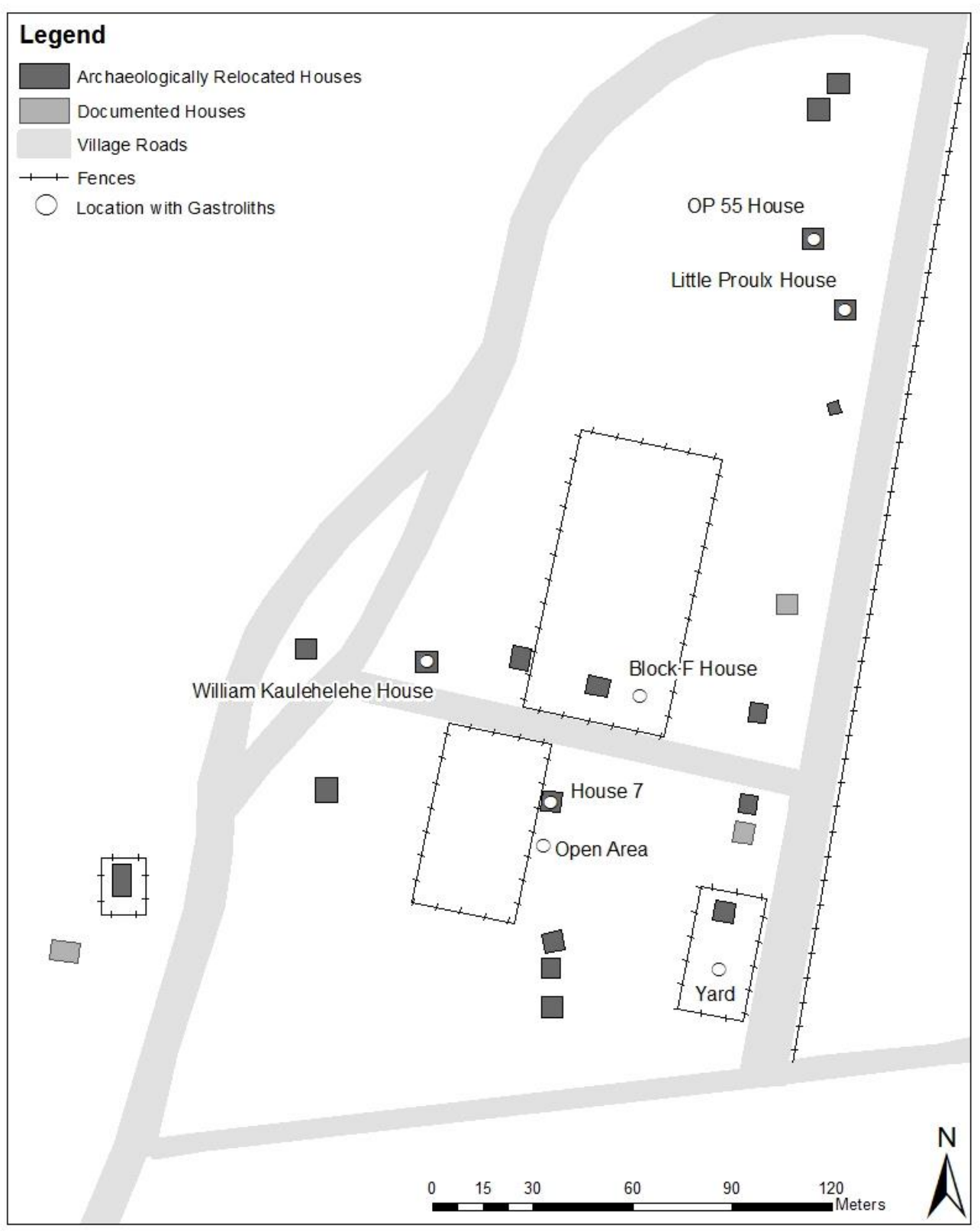

FIGURE 2. 


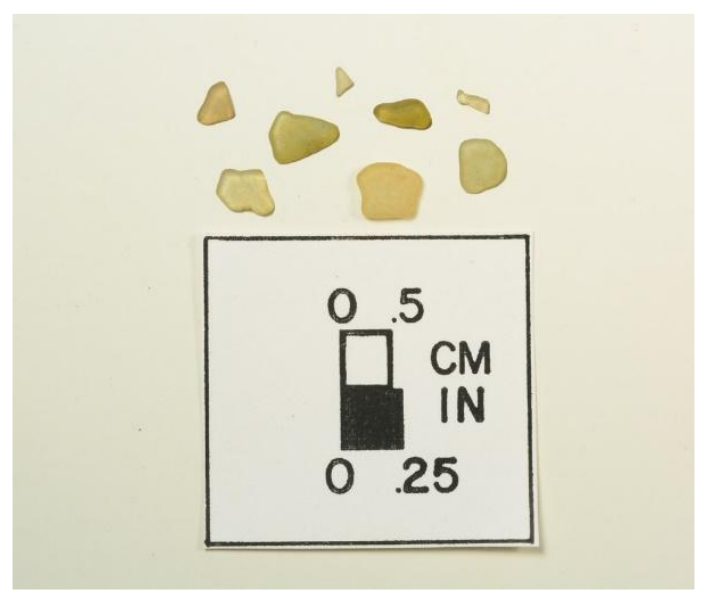

FIGURE 3.

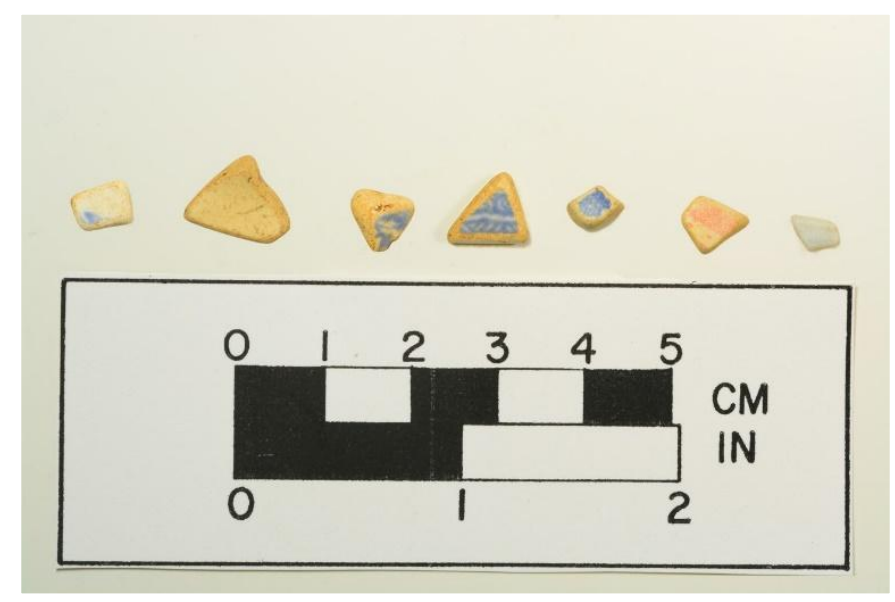

FIGURE 4. 


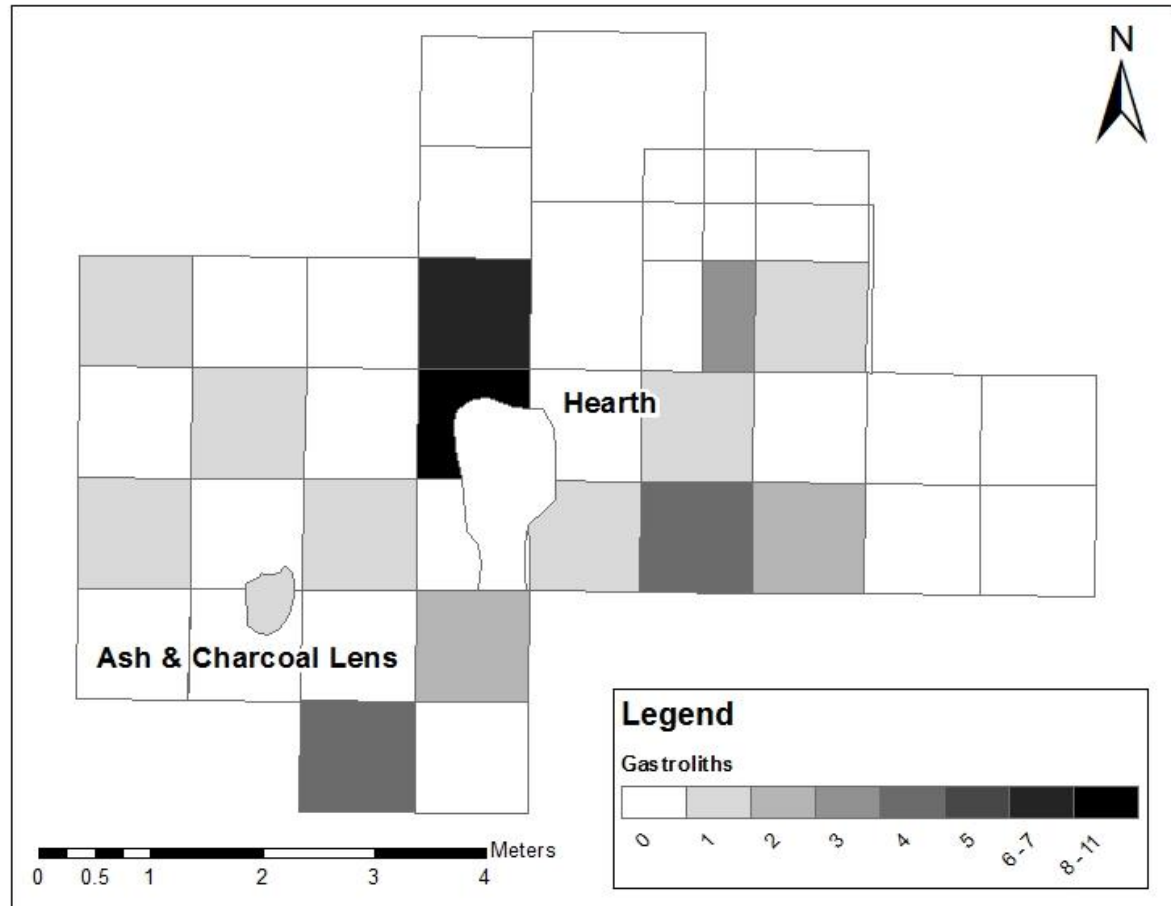

FIGURE 5.

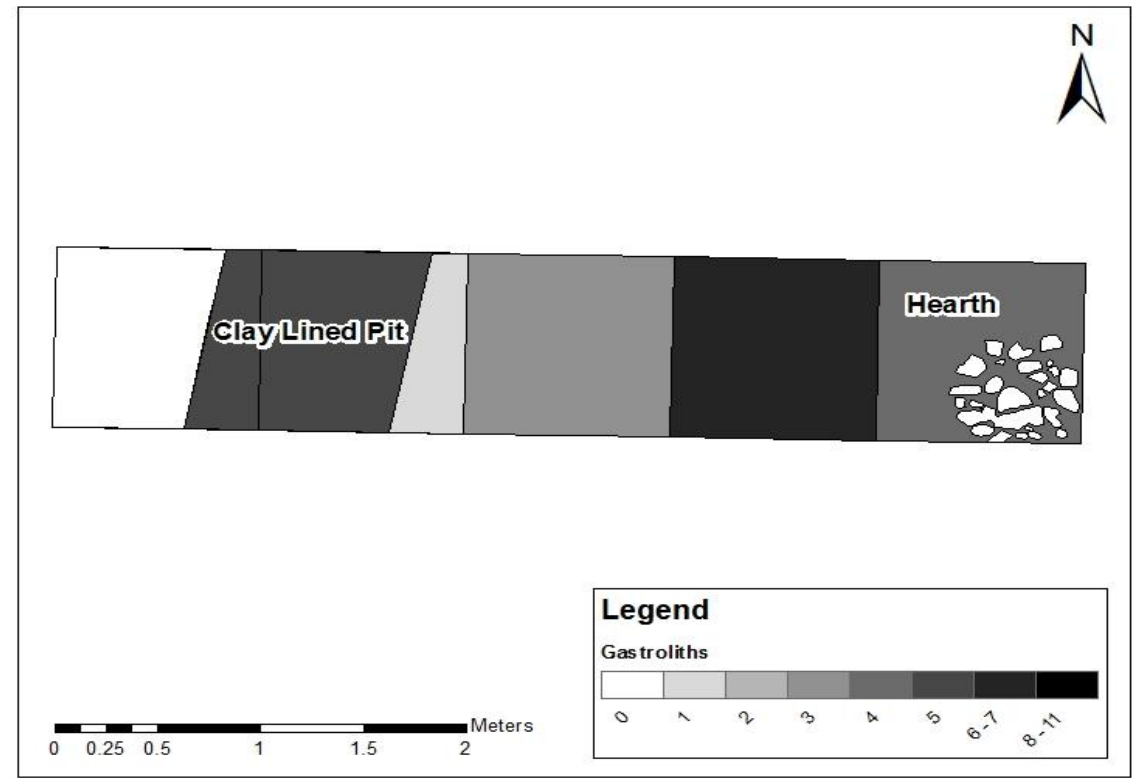

FIGURE 6. 